\title{
ORIENTAÇÃO À QUEIXA ESCOLAR: DESENHANDO UMA NOVA PRÁTICA PARA O PSICÓLOGO CLIINICO ${ }^{1}$
}

Gisele Toassa*

Como vencer a assepsia técnica que contamina o fazer do psicólogo escolar? É possível a emergência da criatividade docente, afogada em rotinas? É viável um modelo clínico de atendimento à queixa escolar que se contraponha aos enfoques psiquiatrizantes? "Orientação à queixa escolar", livro organizado (e majoritariamente escrito) por Beatriz de Paula Souza, psicóloga do Serviço de Orientação à Queixa Escolar do Instituto de Psicologia da Universidade de São Paulo (SePE-IPUSP), é uma inspirada coletânea estruturada em 6 partes e 18 capítulos. Compõe-se, principalmente, de textos de professores do IPUSP, de alunos e ex-alunos deste Instituto (alguns destes ligados ao SePE durante a graduação ou no curso de aperfeiçoamento por ele proporcionado). Incluem-se relatos de pesquisas recentes que, não fosse a coletânea, ainda estariam algo limitados a teses e dissertações.

O livro registra também reflexões e "causos" concretos ligados à elaboração de uma práxis antitecnicista no campo da psicologia escolar, propósito evidente tanto nos seus conteúdos quanto na linguagem despretensiosa dos autores. A prioridade do SePE recai sobre a observação, o diálogo, o entendimento das situações singulares das crianças/adolescentes e a circulação dessas informações na rede de relações em que a queixa escolar ganhou vida. A companhia reflexiva é principalmente do materialismo histórico-dialético, da Escola de Frankfurt, de Foucault, Guattari \& Rolnik, Deleuze, Hanna Arendt, Bleger, Winnicott, Emília Ferreiro, além de docentes do IPUSP, como Ecléa Bosi e Maria Helena de Souza Patto.

"Orientação à queixa escolar" busca o conhecimento do cotidiano escolar brasileiro (sobretudo paulista) desvelando os impactos microscópicos de algumas medidas políticas desastrosas (como a progressão continuada e a persistente rotatividade de professores) na construção das queixas. Livro de interesse tanto para profissionais psicólogos quanto para estudantes de graduação e pósgraduação, seus textos elevam a um primeiro plano o papel da instituição escolar na constituição da subjetividade, deslocando o foco dos problemas de aprendizagem para os de escolarização, tal como em Proença (2002). Idéias winnicottianas mostram uma alternativa aos paradigmas dominantes de psicologia do desenvolvimento, que ainda persistem, na defesa de uma preeminência onipotente do papel da família no desenvolvimento infantil.

Para Souza (2007), a clínica pode ser um tempoespaço muito significativo na superação de queixas individuais, cuidando dos sofrimentos e fracassos que podem permanecer cristalizados caso não recebam atenção na sua história singular. Nesse contexto, a intimidade das escolas paulistas é problematizada com empatia e inteligência: a autora debate os funcionamentos produtores do fracasso e da queixa, tais como mudanças de educadores, convocações de última hora, ausência de espaços de reflexão, desqualificação dos saberes docentes. Nesse contexto, através de Luiz Fernando de Oliveira Saraiva (entre outros autores), a coletânea desenha uma territorialização da produção da queixa escolar, engendrando idéias e atitudes capazes de potencializar as soluções providenciadas pela rede de sujeitos, para além da costumeira ênfase em seus déficits: aposta-se na restituição do desejo de ensinar-aprender, não na avaliação de uma inteligência estática da criança com o uso de testes psicológicos. A relação psicólogofamília-escola, inspirada nas consultas terapêuticas de Winnicott, constitui-se num processo de orientação breve e focal. Em geral, começa com uma triagem, passando por encontros com a criança, contatos (com

Apoio: $\mathrm{CNPq}$.

SOUZA, B. P. (Org.). (2007). Orientação à queixa escolar. São Paulo: Casa do Psicólogo.

Doutoranda em Psicologia Escolar e do Desenvolvimento Humano, Instituto de Psicologia, Universidade de São Paulo-USP. 
a escola, os pais e/ou outros profissionais envolvidos na queixa), entrevista devolutiva e acompanhamento (Freller et al., 2001). Os grupos de pais ou de crianças são sempre valorizados como espaço de apoio, orientação e criação de alternativas, tendo o psicólogo como catalisador de seu acontecer, sem abrir mão da defesa da luta mudança das atuais políticas educacionais.

Ao contrário da tradicional anamnese de modelo médico, um novo rol de preocupações surge a partir do conhecimento dos funcionamentos da escola pública, rotineiramente perpassados pelos preconceitos de poder ante as minorias (negros, nordestinos, população prisional etc.) em nosso país. $\mathrm{O}$ texto de José Moura Gonçalves Filho, providencial, pungente, dolorido, toca-nos com a experiência de humilhação dessas minorias, tão numerosas no atendimento à queixa escolar; atendimento cego à humanidade esquecida em cada trabalhador humilhado, em cada família agredida. Marilene Proença mostra-nos que essa ignorância do psicólogo é dupla: ignorância não só sobre as famílias, mas também sobre a cena escolar.

A crítica resultante é essencial e genética (essencial porque atinge as principais características sócio-históricas do seu objeto; genética, porque se aprofunda nas determinações do problema), possibilitando-nos compreender a queixa escolar como fenômeno dependente de preconceitos, atitudes, dominações, ignorâncias e mal-entendidos que interagem no sofrer das crianças, suas famílias e escolas. Os textos complementam-se mutuamente, trazendo uma nova abordagem da queixa escolar, que, para Souza (2007), é a principal em saúde mental infanto-juvenil no Estado de São Paulo.

\section{REFERÊNCIAS}

Freller, C. C., Souza, B. P., Angelucci, C. B., Bonadio, A. N., Dias, A. C., Lins, F. R. S. \& Macêdo, T. E. C. R. de. (2001). Orientação à queixa escolar. Psicologia em Estudo, 6(2), 129134.

Proença, M. (2002). Problemas de aprendizagem ou problemas de escolarização? Repensando o cotidiano escolar à luz da perspectiva histórico-crítica em psicologia. Em M. K. Oliveira, D. T. R. Souza \& M. T. Rego (Orgs.), Psicologia, educação e as temáticas da vida contemporânea (pp. 177-196) São Paulo: Moderna.

Souza, B. P. (Org.). (2007). Orientação à queixa escolar. São Paulo: Casa do Psicólogo

Endereço para correspondência: Gisele Toassa. R. Caiubi, 372, Apto.22, Perdizes, CEP 05010-000, São Paulo-SP. E-mail: gtoassa@yahoo.com.br 